\title{
FOURIER GRAIN SHAPE ANALYSIS: A MEANS FOR CORRELATING ALLUVIAL DEPOSITS AT THE NEVADA TEST SITE
}

\author{
B. T. Grothaus \\ G. L. Hage
}

October 18, 1978

Work performed under the auspices of the U.S. Department af Energy by the UCLLL under contract number W-7405-ENG-48.






\section{近}

\section{IAWRENCE LIVERMORE LABORATORY}

University of Cakfornia Livermore.California 94550

UCRL-52569

\section{FOURIER GRAIN SHAPE ANALYSIS: A MEANS FOR CORRELATING ALLUVIAL DEPOSITS AT THE NEVADA TEST SITE \\ B. T. Grothaus* \\ G. L. Hage}

MS. date: October 18,1978

* Present address: Geology Department. University of South Carolina. West Columbia. SC. 


\section{CONTENTS}

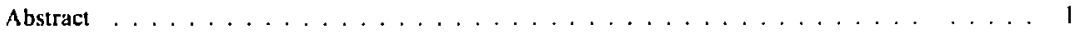

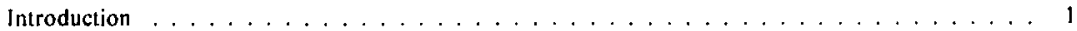

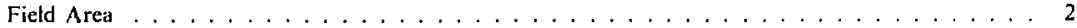

Sampling ................................. 4

Analysis .................................. 4

Mean Harmonic Amplitude Spectra . . . . . . . . . . . . . . . . . . . . . . 4

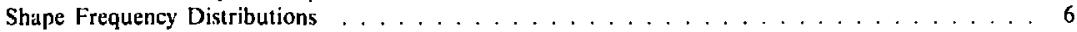

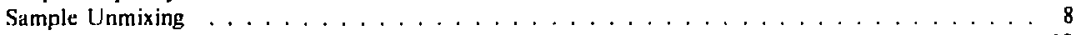

Discussion and Conciusions . . . . . . . . . . . . . . . . . . 10

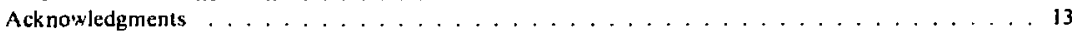

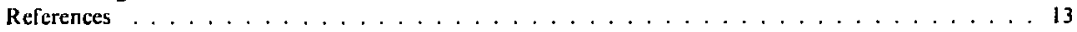




\title{
FOURIER GRAIN SHAPE ANALYSIS: A MEANS FOR CORRELATING ALLUVIAL DEPOSITS AT THE NEVADA TEST SITE
}

\begin{abstract}
Quartz sand derived from alluvial fans that drain different lithologies at the Nevada Test Site can be distinguished on the basis of grain shape as described by the Fourier series in closed form. Specifically, we examined tuff units from the Piapi Canyon and Indian Trail Formations as well as carbonate-bearing clastic units from the Eleana Formation.

Discrimination between rock types was accomplished by examining the mean harmonic amplitude spectra and the grain shape frequency distributions at those harmonics that exhibit "significant" chi-square values. The results of these analyses indicate that the tuffs can he easily distinguished from the clastics. However, differences between samples from genetically similar rock types are not as prominent. Grain shape frequency distributions of tuffs and clastics show such strong differences that they can be characterized by standardized distributions. By comparing the shape frequency distributions of mixed sediment samples, it is possible to determine the relative contribution of tuff and clastics 10 any sediment sample taken within the drainage network.

The Piapi Canyon, Indian Trail, and Eleana Formations have produced the thick alluvium sequence in the Rainier Mesa region of Yucca Flat. We believe it is likely that these grain shape relationships can also be applied to subsurface samples. Not only would this extended application enable more accurate correlation of alluvial layers. but more precise determination of the clastic-tuff contact within the alluvium sequence might also be possible.
\end{abstract}

\section{INTRODUCTION}

The physical properties of alluvium (e.g., buik and grain density, resistivity) must be analyzed befure the emplacement of each device at the Nevada Test Site (NTS). Beciluse of the complexity of the alluvium. this is a tedious process requiring eareful analysis of various geophysical logs. If we could correlate the alluvium by outlining zones possessing similar physical properties this netessary analysis would be greatly simplified. However, until now, only two methods-examining downt:sle stereo photographs to identify debris flow deposits. and inalyzing electrical risistivity logs-have yielded even moderate suceess.' The major problem in correlating alluvial layers arises from the fact that they consist largely of louse gravels contributed from a variety of soures rocks. The relative proportions of the grivels from each source are very difficult to assess from geophysical logs and sidewall samples.

In this investigation, we wished to determine the extent to which shape analysis of quartz sand grains in an alluvial fan environment. such as the NTS, can be used to discriminate between source rocks. If different rock types and subsequently different alluvial fans yield characteristics grains, it should be possible to predict the relative proportions of various sediment types being contributed to any point of fan confluence in the drainage network. In addition, it should also be possible to gain some knowledge of the attrition rates of any rock type (source population) in relation to another because different rock types have vitriable resistances to chemical and mechanical effects with increased distance of transport. 
Previous investigations have shown that the shapes of sand-size quartz grains reflect, to some degree, characteristics acquircd during their original formation (e.g., due to pressure and temperature) and during subsequent transport and deposition after erosion. ${ }^{2}$ On the basis of these premises, quartz has been used as a natural tracer to differentiate between source areas and to determine the relative proportions of sediment in a mixed source deposit. 3.4 However, ours is the first attempt to use this process in an area where sediment movement occurs only by surges following nash storms, not by free flowing streams and longshore drift.

The grain shapes were measured using the Fourier analysis technique developed by Ehrlich and Weinterg. ${ }^{5}$ This technique utilizes a Fourier series in elosed form to describe each grain as precisely as desired. The Fourier series consists of a progression of terms (harmonics) in which each hatmonic represents the contribution of a specific geometrical component to the total shape. For exansple, the amplitude of the second harmonic represents the contribution of a two-lobed grain shape (figure-eight), the amplitude of the third harmonic represents the contribution of a three-lobed grain shape (trefoil), and the amplitude of the $n$th harmonic represents the contribution of a grain shape with N lobes. Thus, grain shape can be measured as precisely as desired by progressively adding terms. In previous studies, we determined that the first 20 harmonics provide sufficient detail: thus, these were all we used in this present investigation.

\section{FIELD AREA}

The study area selected for this project is the Rainier Mesa region in the western portion of Yucca Flat. NTS (see Fig. 1) and covers portions of Areas 12, 8 , and 2. This area has been mapped in detail by Gibbons et al. ${ }^{6}$ Gibbons et al., have also made quite complete lithologic descriptions of the st ratigraphic formations, each of which consists of a series of lithologic units (e.g., zeolitized and welded tuifs), hereafter referred to as units. The drainage system consists of a network of braided ephemeral strams that transport sediment from small alluvial fans to a single large "catchment" fan which covers much of Area 2 and the western portion of Area 9. The lithologic variation among the source areas and the relatively short distance of sedirient transport create a good field laboratory in which to conduct such a study.

The rock types being eroded corisist largely of carbonate units with associated clustics and volcanic tuff units. These same units occur at depth beneath the alluvium at NTS. Thus, this intermontane basin, Yucca Flat, is slowly being buried beneath the debris erading off the surrounding foothills. Three different formations have been defined as the major sediment contributors to the drainage system. However, as stated above, there are essentially only two major rock types. The following lithologic descriptions, based primarily on the work of Gibbons et al., describe each of the units sampled.

The sample 1 locality drains units $E, F$, and $G$ of the Eleana Formation (MississippianPennsylvanian). Similarly, sample 5 drains tnits E, 1 , and $H$ of the same formation. These units consist of grey and brown quartzite and sandstore, con- glomerate, crystalline limestone, and red and grey argillite.

Sample 2 is taken from a stream that drains an area underlain by dolomite of the Eleana Formation. The area where we took the sample should be influenced by all three of the dolomite units. These dolomite units consist of fine crystalline to fine grilined dolomite with occasional crossbeds and ripple marks in the middle unit and white breccia in the upper unit.

Sample 3 was laken from fans draining Tertiary Tunnel Beds I through 4. These Tunnel Beds consisı predominanily of zeolitic bedded tuffs with Iwo zones of pisolite beds in Tunnel bed $I$.

Simple 4 was taken from a stream that drains an area underlain by two younger tufts, the Survey Butte tuff and the Rainier Mesa member of the Timber Mountain Formation. The Survey Butte tuff consists of ash-fall turf, locally reworked and locally zeolitized in the lower $100 \mathrm{ft}$. The Survey Butte tuff is probably a composite ash-fall tuff that is genetically related to all ot her members of the formation. In contrast, the Rainier Mesa tuff is a multiple-flow, compound-cooling unit of welded and nonwelded tuffs that grade into a nonwelded tuff at the bise of the cooling unit. Rainier Mesa tuff is composed of rh olite and quartz latite, and contains abundant phe locrysts of quartz, sanidine, and plagioclase. The welded tuffs are much more resistant and outcrop as cliffs. (From here on, this sample 4 will be referred to simply as the younger tuffs sample.)

Sample 6 is a mixed sample that may be influenced by source contributions from units characterized by simples 1,3 , and 4 . However, in relation 


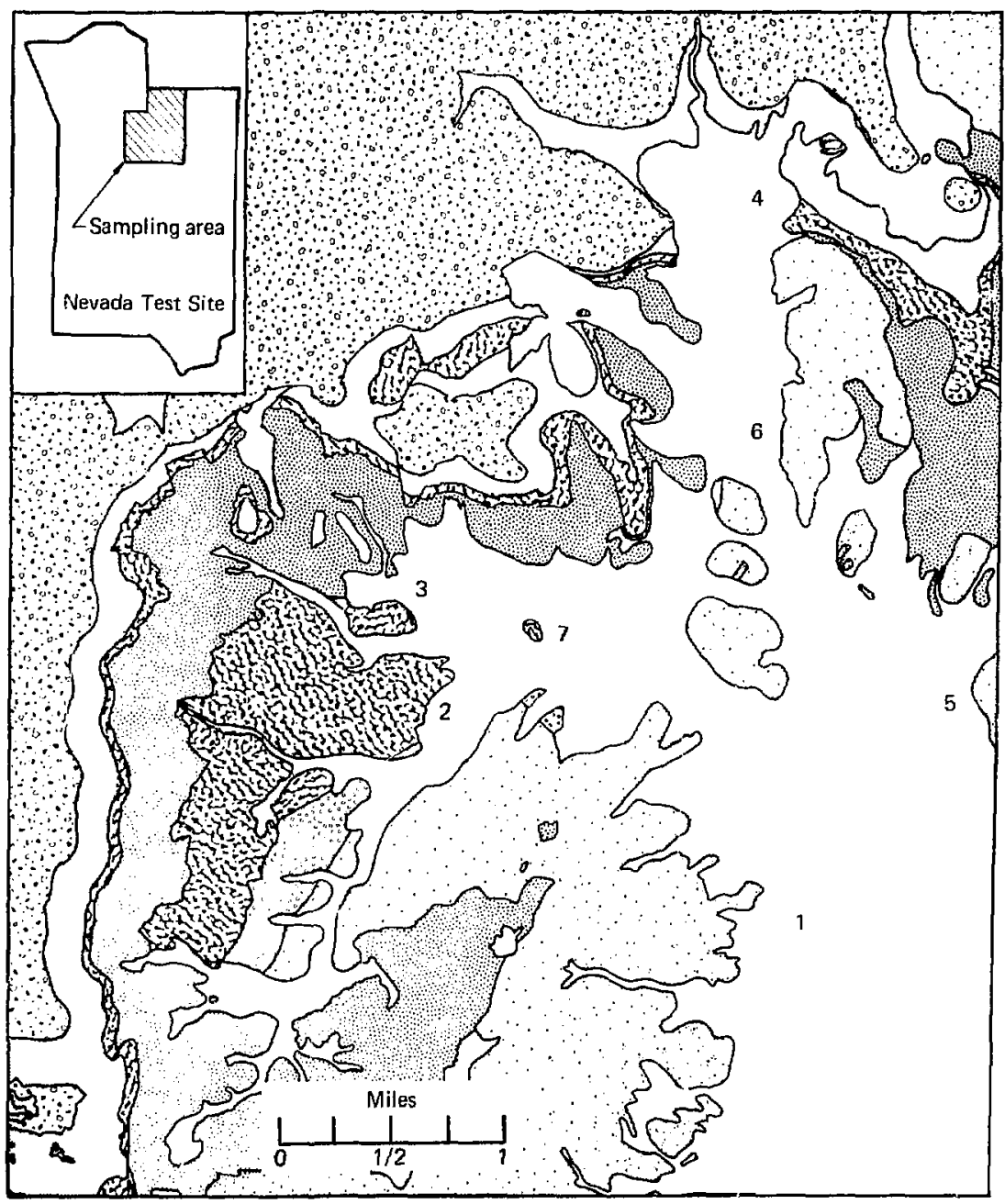

lig. I. Mlap of the stedy area for this project This is the Kainier Mlese region in the western portion of Yurca Flat. Meradu lest Site. This ins:t shows the outline of the VIS, the shuded hlock locates our study area. Sample localions are shown: 11 , f.lcana elasties. 121 Fle unu dulomites, (3) Indian Trail tuffo, (d) Piapi (anjon tuff, (5) Elleana clastics, (6) mixed sample, und (7) mixced sample. 
to the lotal effective druinage area, the drainage from the Tunnel Bed units is minimal. The erosional surface area of the Tunnel Bed units is proportionately very small.

Sample 7 is atso a mixed sediment sumple. It was laken from the confluence of ephemeral streams that drain sample locations 2 and 3. mixing dolomite from the Eleana Formation with Tertiary tuffs from the Tunncl Beds. The drainage area from each source is roughly equal.

\section{Sampling}

Stven samples were analyzed. Five of them were taken from the buses of alluvial fars draining different formations and thus represent specific source areas. Care was taken to ensure that the fans sclested drained only one formation. The remaining two simples are mixed source sands that were collected along ephemeral streams down drainage. One of these mixed sands was collected at the conlluence of streum beds draining only two sources and was used to determine which of the two upstream fans is yielding the greater percentage of naterial. The remaining mixed sample was taken directly down drainage from the younger tufis but appears to be receiving some drainage from part of the Eleana formation as well. These mixed samples can bu used to test hypotheses regarding which source is the predominant contributor of sediment.

\section{Analysis}

Samples were wet sieved to separate material into coarsc, medium, and fine sand fractions. This eliminates any size-shape interactions that might bias the results. Because of time constraints, we were only able to andalyze the fine sand fraction of each sample. The other size fractions were set aside for possible later use. After sieving, the sand was poured through a magnetic separator to concentrate the quartz grains. The grains were then washed in a riilute solution of hydrochloric acid and stannous chloride to dissolve any carbonate minerals and to remove iron oxide coatings. Finally, the sands were immersed in a dilute hydrofluoric acid solution to break down the feldspars. After drying, the sainples were divided into approximately 200 -grain portions and mounted on petrographic slides.

Two-dimensional outlines of the maximum projection perimeters were drawn using a Leitz Wetzlar mieroscope with a viewing screen. These outlines were then digitized as a sequence of $48 \mathrm{X}-\mathrm{Y}$ coordinates and stored in computer memory. These raw data files serveo as input for cullouting the Fourier series of each sample. The harmonic amplitude values determined by the Fourier series are then normalized by dividiug each value by the zeroth harmonic amplitude (mean radius). The first 20 harmonics were calculated for each grain. Each sample consisted of approximately 200 grains. Thus, each sample was characterized by 4000 data points.

\section{MEAN HARMONIC AMPLITUDE SPECTRA}

Mean harmonic amplitude spectra (MHAS) provide a quick and simple method for graphically displaying the "average" grain shape characteristics of a sample. By plotting the mean amplitude values at each harmonic (which requires only the ouiput from the Fourier program), the MHAS often can be used without further sophisticated analysis to distinguish between different rock types. Two tuff samples are compared with the Paleozoic sedimentary units in Fig. 2, demonstrating the utility of MHAS. The harmonic numbers are plotted aloug the $\mathrm{X}$-axis and the curresponding mean amplitude values are plotted along the $Y$-axis. There is a consistent divergenee of the tuff and clastic curves at all harmonics except the third, indicating that the tuffs ctin be clcarly distinguished from the clastic-bearing sedimentary units. All samples demonstrate similar mean amplitude values at the third harmonics.

When we compare the younger tuffs and the Tunnel Bed tuffs, we see that the vounger tuffs sample tends toward slightly lower mean amplitude values at most harmonics. Although this difference is small, it does reflect the fact that these grains more closely approach circularity than do those of the Tunnel Bed tuffs.

When we examine the MHAS curves of samples taken from the Eleana Formation, we see that the curves diverge from one another at some harmonits. but no systematic differences can be observed. Such a puttcrn indicates strong similarity in grain shape between samples. 


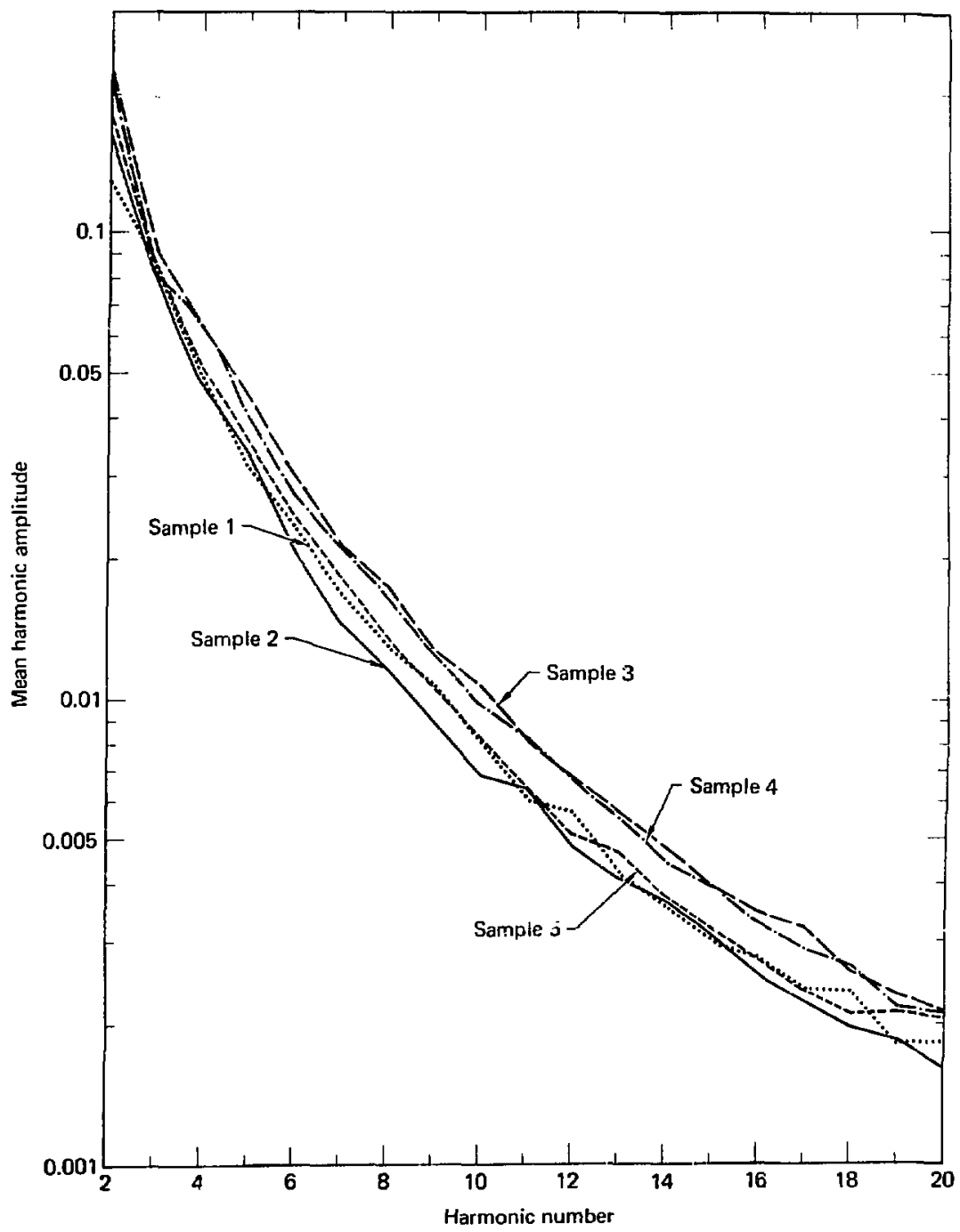

Fig. 2. Plot of mean harmonic amplitude vs hamonic number tor the flve source locality samples: $-\cdots$ sample 4 (Survey Butte and

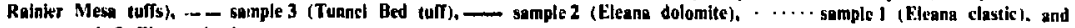
- - sumple 5 (Eleang clastic). 


\section{SHAPE FREQUENCY DISTRIBUTIONS}

Yarus $^{7}$ established that the underlying shape frequency distributions of single lithologies arte often polymodal. Therefore. it is unlikely thit the MHAS reflect ill the distinguishing properties of these sediments. In in attempt to analyre these differentes more precisely, we examined the shape frequency distributions.

In contrist to the MHAS, shape frequency distributions can precisely locale the differences. To obtain these distributions. the range of amplitude values an each harmonic is first divided into 20 equal intervals. Shape frequency distribution histograms afe then constructed by plotling harmonic am. plitude $r$ s the number frequency at these specified intervals. Thus, each sample is characterized by 20 hislograms.

Using chi-square contingency tables. we compared shape frequency distributions at each harmonic for different source rocks. The chi-square slatistical test is preferred because it does not assume id normal distribution. It would be tedious and possibly siatistically invalid to make all possible conparisons between rock types. Therefore. we chose is set of orthogonal con:rasts with which to analyze for similarities and differences between sources.

Figure 3 presents the various comparisons made and the corresponding harmonics at which significant differences occurred. Significant chisquare values indicate large differences between samples and therefore mark those harmonics at which perceptible differences are likely to occur between histurams.

In the first comparisun. we combined the three samples from the Eleana Formution and contrasted them with the two tuff samples. Significant dif- ferences oceurred al all harnonics except the third: 17 of the 20 harmonics showed significunce at the 0,0005 alpha level. The sharp contrast between tuffs and clastic-beuring sedinentary units in Rainitr Mesa. as observed by analysis of the MHAS, is verified with this probabilistic test. The largest of the signifieant values occurs at the second harmonic. When we exansine the histograms for all samples at this harmonic, we see that the significant dilfercnees result from the presence of a large mode on the left of the clastic samples and the corresponding lack of low amplitude values on the left of the tuff histograms (Fig. 4). An equal but opposite effect applies to the right side of these two histograms. Thus, it appears that the clastics are characteriaed by a high percentage of "uvoid" grains at the second harmonic, whereas the tuffs are dominaled by a high percentage of "elongate" grilins.

In the sccond comparison. sample I was contrasted with sample 2. Sample I is from the fileana clastics and sample 2 represents l:lean.1 dolomite units. The chi-square table indicates tbat significance oceurs at only 5 of the 20 harmonies; the largest significant value occurs at the 18 th harmonic. When we examine the contributing faclors to the chi-square statistic and histograms at the 18 th harmonic, we see that this significant difference is largely the resuit of a high eentral mode in the sample I distribution.

Sample I n'sis also contrastid with sample 5. Both samples are from tastic units of the Eleana Formation. Although simple 1 was taken from drainage oft units $E:, F$, and $G$, and sample 5 reprssents sediment inllux from units $I:$, and $t$. they should botb reflect a similar depositional history.

\section{Harmonic number}

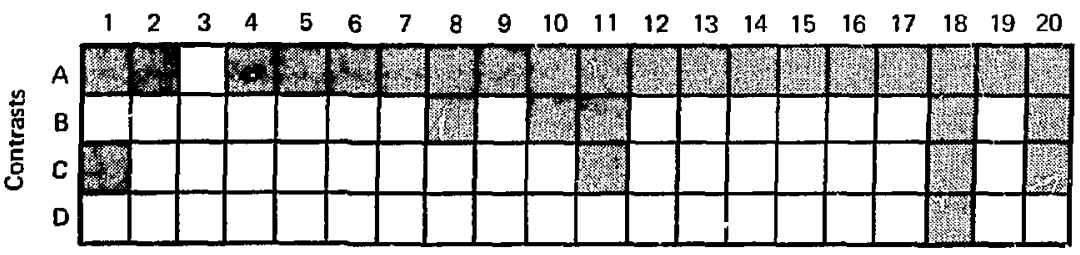

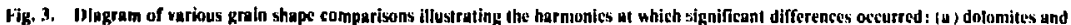

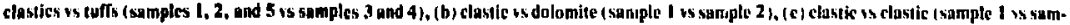
ple 5). and (d) fuff is tutf (sample 3 us sample 4 J. 


\section{CLASTICS}
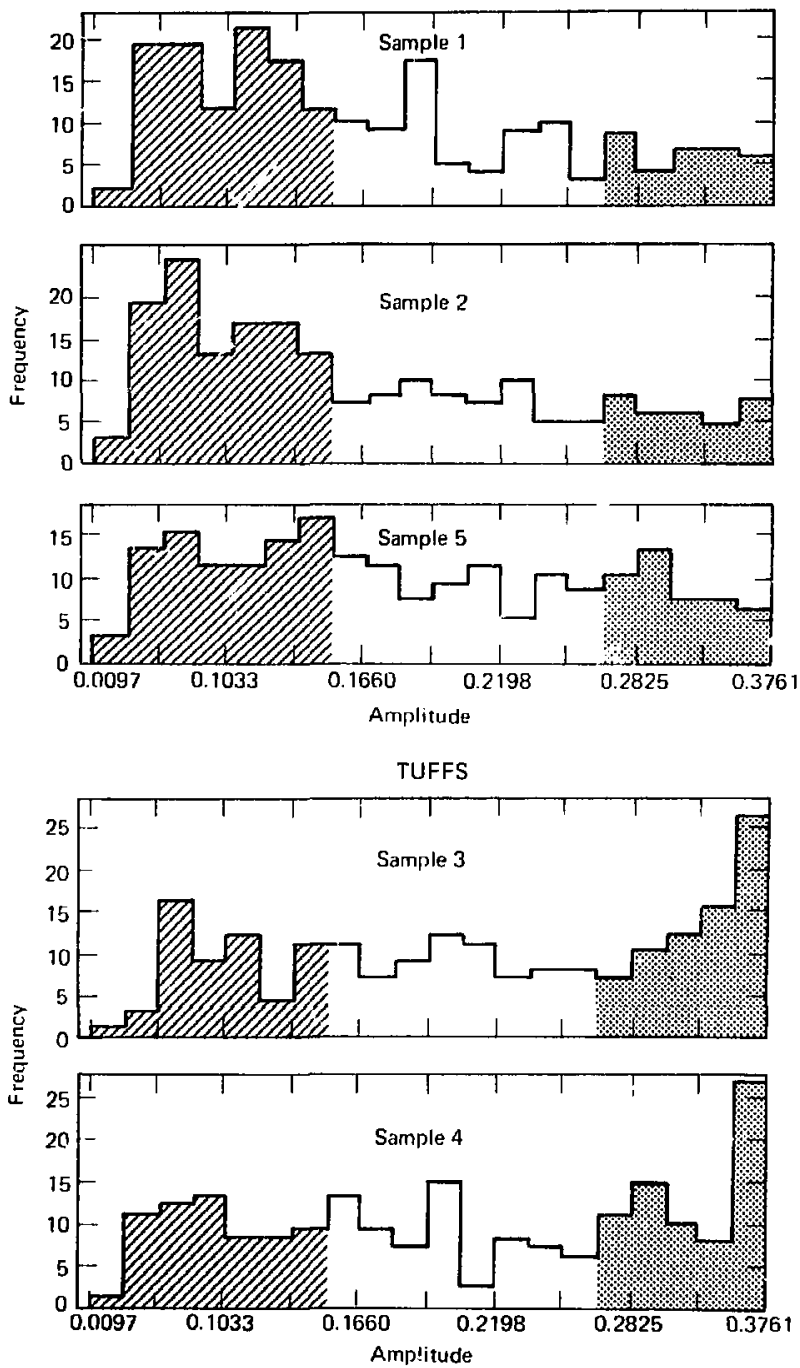

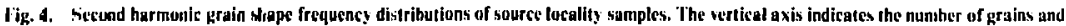
the interials along the horizontal axis indieate the harmonic amplitude (increasing to right). 
Consequently, one would expect these samples to possess similar shape characteristics. Chi-square analysis confirms this conjecture. Signification differences ietween the two samples were found only at four of the 20 harmonics.

Listly, we compared the younger tuffs and the Tunnel Bed cuffs. The only significant contrast occurs al the 18 th harmonic. This difference results from the presence of three small modes within the body of the sample 3 (Tunnel Bed tuffs) distribution that are not present in the sample 4 (younger tuifs) distribution.

The results of these chi-square analyses in. dicale that differences between the tuffs and the clastic sumples from the Eleana Formation are expressed at most of the 20 harmonics. However, variation within the clastic samples or within the tuffs is only evident at a few of the harmonics analyzed. This supports the conclusions of Przygocki that genetically different rock types must produce different shape frequency distributions; conversely, rock types of similar origin commonly yield similar shape frequency distributions.

The shape frequency distributions of the tuffs and clastics are so inherently different that it is possible to describe them by generalized shape frequency distributions. These generalized distributions provide standards to which we can compare the mixed sediment samples. The clastics typically have a large mode on the lef: side of the histogram that steadily diminishes loward the right. The tuffs, however, possess a large mode on the right side that tuils off to the left. This behavior is best illustrated at the second harmonic (fig. 4) but is characteristic of most other harmonics at which chi-square significance occurs.

\section{SAMPLE UNMIXING}

To demonstrate the feasibility of unmixing sand samples into their various source components, a tnixed sample (7) was collected from the confuence of streams draining only two lithologies, Eleuna dolomite and the Tunnel Bed tuffs. Because of the proximity of the source fans and the absence of other sources, we expect this mixed sample to contain grains from each of these units in unknown proportions. In Fig. 5, the MHAS of samples from all three of these areas are compared. The graph clearly indicates that the mixed sample curve most closely approaches that of the dolomite. Thus we conclude that the majority of grains contributed to the mixed sample are from the dolomitc units.

To furcher analyze these results, we used a chisquare contingency table and proposed hypotheses to tesi for differences between the three samples (Fig. 6). The results confirm the initial findings of the MHAS as in Fig. 5. The only significant differences between the mixed sample and the dolomite occurred at the 4th, 7th, and 10th harmonics. However, the mixed sample and the tuff differed significantly at 10 of the 20 harmonics calculatyd. Both sources differed significantly from the mixed sample at the 10th harmonic. More importantly, the l0th harmonic showed the highest statistical significance of the 20 harmonics when we compared the two source samples.

To better understand these relationships, the shape frecuency histcyrams at the 10:h harmonic were contrusted for the three samples-dolomite, tuff, and mixcd sample. Figure 7 illustrutes the portions of the mixed sample histogram influencers most by the respective source areas. We note that the mixed sample has a high proportion of "low amplitude" grains, as indicated by the large left mode. and a corresponding dearth of high amplitude values, as illustrated by the small right mode. Both features are dominant characteristics of the dolomite standard.

Having made the assumption that the only two contributing sources (approximately equal in arei) to the mixed sumple locality are the dolomite and the tuff, we can calculate the relative proportions contributed from each. To avoid possible complex shifting of internal modes, it is best to compare histograms at a harmonic where the tails vary greatly. Thus, we select $\checkmark$ the 101 h harmonc where $46 \%$ of the grains fro $\pi$ the tuff have an amplitude greater than 0.010664 , but only $21 \%$ of the dolomite grains have amplitudes greater than 0.010664 . Surpu isingly, $21 \%$ of the mixed sample grains fall in this amplitude range.

The seemingly obvious reason for the ideutical percentages of the dolomite and mixed samples in the high amplitude range is that little, if any, of the sediment in the mixed saraple locility comes from the tuff. Although this is true for the particular sample analyzed, we must answer several questions before we can extrapolate this conclusion to the entire area sampled. Namely, is the tuff being eroded 


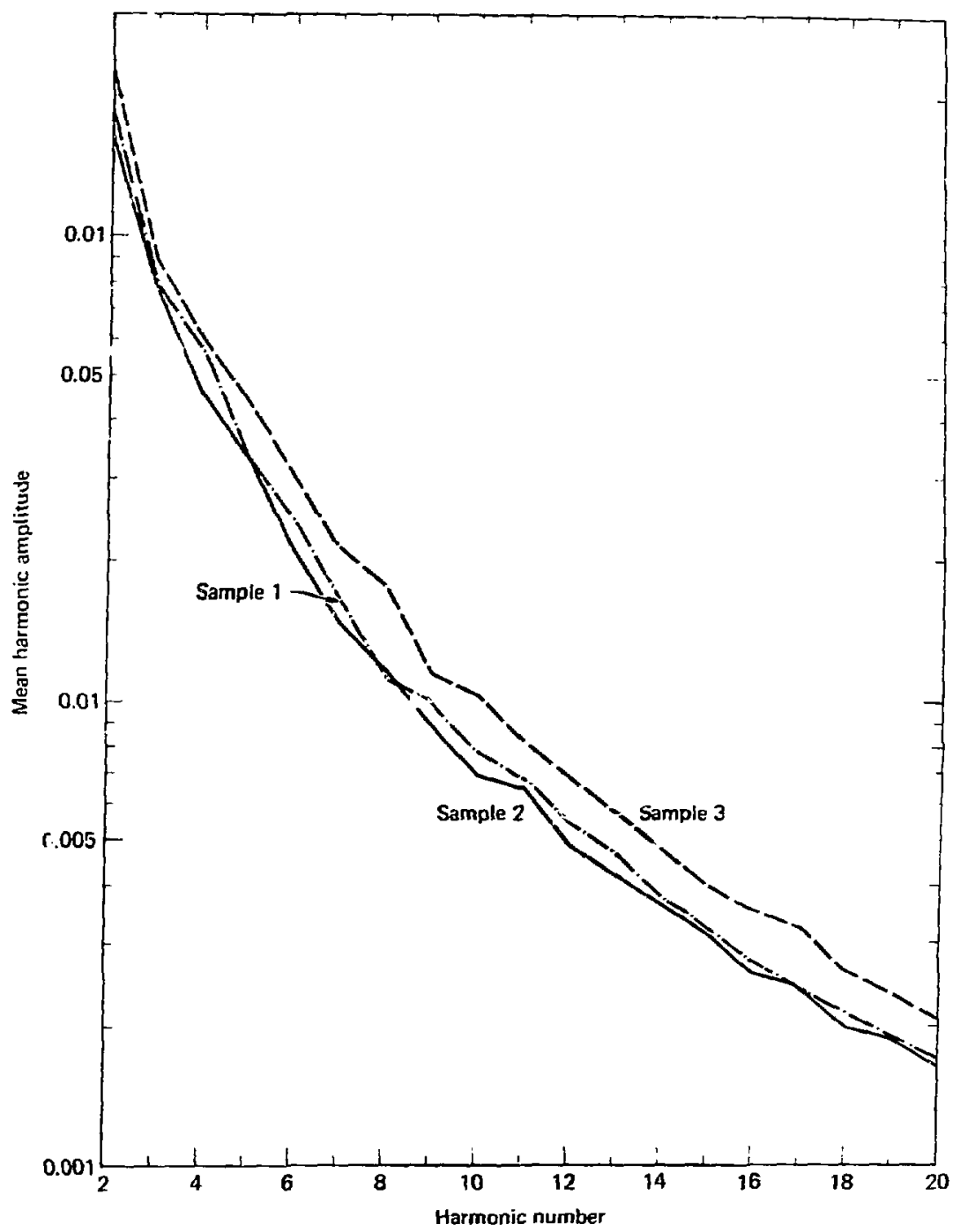

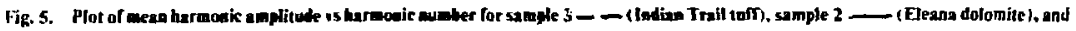
sample $7 \ldots . . . \cdot$ (nixed stuple). 


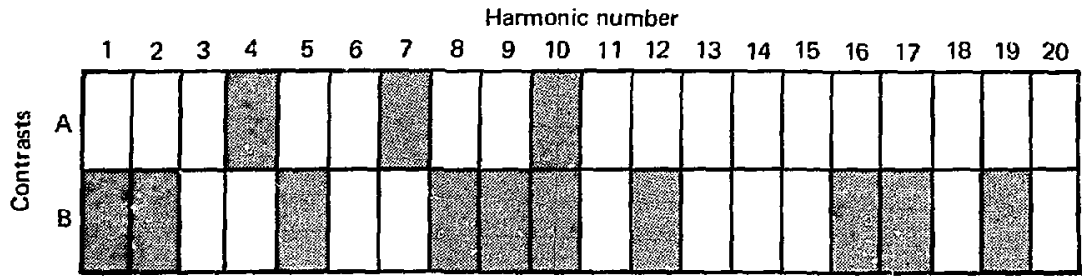

Hig. 6. Diagram of two grain shepe conparisons illustrating the harmenics at which significant differences occur: (2) dolomite vs mixed sample (sumple 2 ys sample 7) and (b) tuff us mixed sample (sample 3 is sample 7).

at a rate similar to that of the dolomite? If it is, are all sand sizes transported from the sources in the same proportions or are the above percentages unique to the fine-sand class? Also, what is the relative percentage of quartz in the parent rocks? Finally, is the sedinent stratified? Such questions would be answered much more easily if we could use a scanning digitizer in conjunction with a microscope; with such hardware, thousands of grains could be analyzed in just a few hours.

Sediment stratification may well be the dominant sedimentation process. For example, during a flash thunderstorm, scdiment may be eroded from one canyon, but an adjacent canyon may remain dry and experience little or no sediment erosion. Such a phenomenon would produce a layering offect downstream of homogeneous deposits that represent a single lithology. not a uniform mixture of sediments. The possible occurrence of such a phenomenon needs to be further evaluated before our analysis can be extended to subsurface correlations.

Another mixud sample (6) was taken at the confluence of streams that drain the sample 4 loc'lity, the Tertiary Tunnel Beds, and the Eleana clastic units D, E, and F. Because the Tunnel Beds represent a very small exposure in relation to the total effective drainage area and because they are statistically quite similar in grain shape to the younger tuffs, only samples 4 and 1 (representing the Eleana clastics) were contrasted with the mixed sample 6 .

As expected, the tuff sample differs significantly from the clastic sample at 14 of the 20 harmonics. Also, the clastic sample is significantly different from the mixed sample at 12 of 20 harmonics. The tuff sample, however, does not differ significantly from the mixed sample at any harmonics. These results imply that, as with mixed sample '. almost all the quartz sand in the sample sediment is b sing contributed from one rock type alone. In sample 6. the tuff is the major sediment supplier: in sample 7 , the dolomite units are the dominant source. However, with sample 6, the results were more predictable bectuse the greater percentage of drainage area is from the tuffs. Only two small feeder streams are entrenched in the Eleina outcrops.

\section{DISCUSSION AND CONCLUSIONS}

Fourier grain shape analysis has enabled us to investigate differences in quartz grain shape in sedjments drairing areas underlain by Tunnel Beds, Survey Butte, and Rainier Mesa tuffs, as well as clastic units of the Eleana Formation. It is a relatively simple matter to discriminate between tuffs and clastics, but differences between genetically similar rock types are not as prominent.

The tuffs are volcanic in origin and thus contain quartz shards that are, by definition, quite angular. The shapes of these quartz grains reflect the complex interaction of cooling rate and pore space available at the time when the tuff was formed. The tuff has since undergone erosion, producing the sand we sampled. However, the flash floods characteristic of a desert alluvial fan environment apparently have not significantly altered this angular quality.

In conurast, the quartz grains within the sedimentary units of the Eleana Formation may 

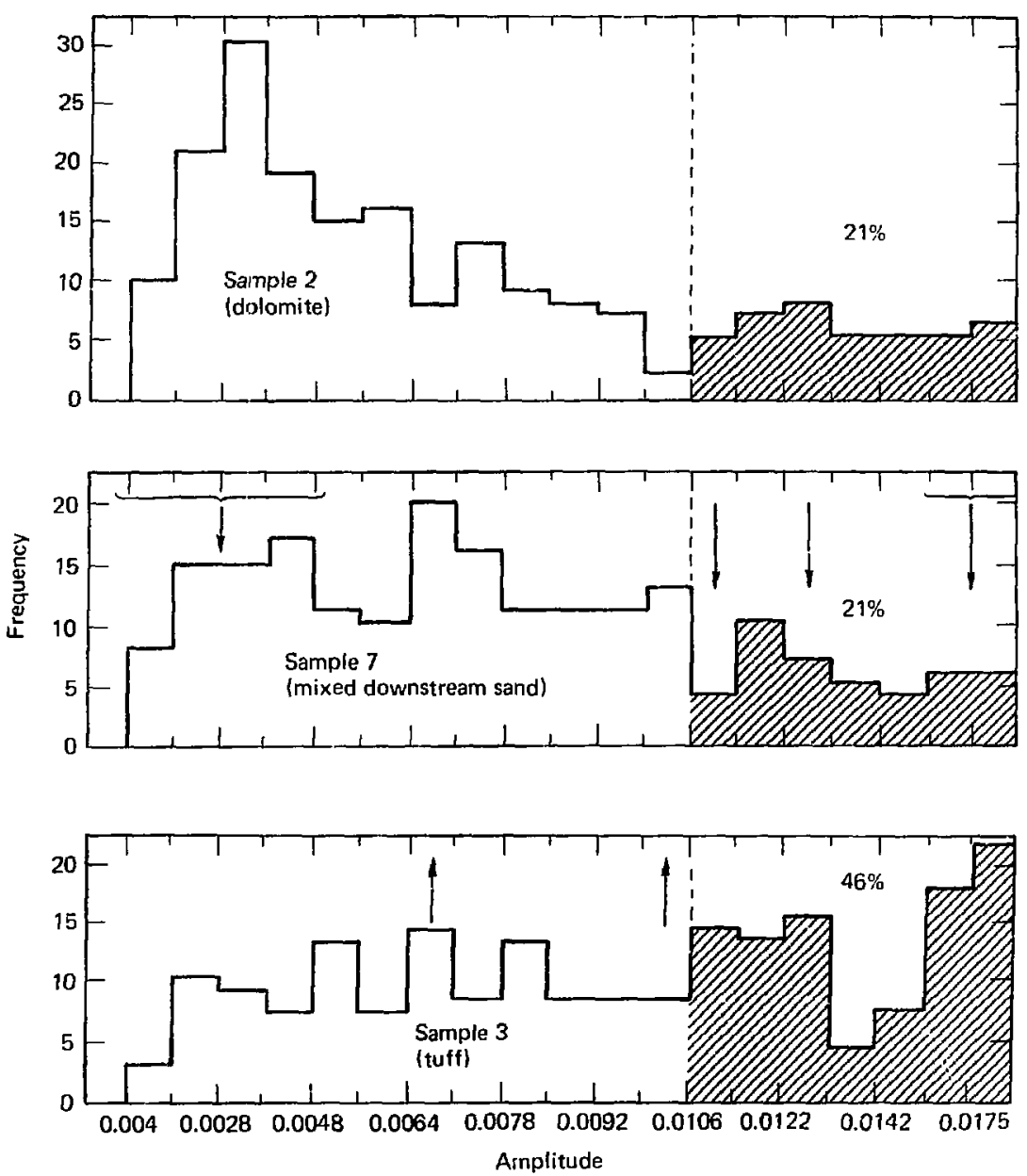

Fig. 7. Tenth harmonic grain shape frequency distributions of the mixed sample (7) histogram stowing portions of uhe histogram most influenced by the respective source areas. The rettical exis indicates the number of grains and the intervals along the horizontal axis indicate the harmonic amplttude (increasing to right).

have undergone several cycles of erosion, transport, and deposition before reaching the sampling sites at NTS. Although some shape components charac- teristic of their origin may remain, their present shape most probably reflects their depositional history. 
Differences hetween the lufl and clastic units are so great that simple inspection of the mean harmonic amplitude spectra provides sulficient detail for discriminating between them (fig. 2). The chi. square analysis of contingeney tahles further docements these differences. (ising the significant chisyuare balues as a guide, we can conpare histogranss at the steond harnomic lor all source simples (J.ig. 4). These results indicate that the tuff and clastic samaple groups can be described by standard shape freyuency distributions. The luffs are characterised by a large percentage of high anplitude values and a relatively small proporton a: low anplitude values. A roughly equal but upposite relationship charaterizes the clasticts.

On the basis of these observations, we should be ahle to determire whether there has been a significunt influx of sediment from carbonatebearing outcrops to any point of confluence in the drainige system. We can obtain a srude estimate of the proportion of carhonate-bearing aediment present in a mixed sample simply by calculating the percentage of grains in the sample possessing very high anıplitude values. Preliminury estimates based on our analysis of the five source samples indicate that in sands derived only from tuff units, at least $13 \%$ of a 200-grain simple will have amplitudes greater Ihan 0.3679 al the second harmonic. In contrast, in sands derived from clastic units, less than $5 \%$ of the tetal sample will have ampliaades greater than 0.3679 . Accordingly, if these percentages hold trac for additional tests, we would expect that in a variable mixture of sand from both source lithologies, between 5 and $13 \%$ the total sample will have amplitudes greater than 0.3679 .

We examined a mixed sediment sample taken from an area that exclusively drained dotomite outcrops and tuffs, and atlempted to "unmix" the sample using the MHAS technique, the chi-square tests. and the grain shape frequency histograms. Results indicate that the dolomite was the major contributing lithology, even though the drainage area encompassed by each lithology is roughly comparable. However, it is inpussible to draw coriclusions conterning rełative rates of sediment input in this location from the two sources on the basis of the one sample. One possible explanation for the appearance of dolomite as the predominant constituent is that the sediment sample from within this drainuge network is characterized by a layering effect in which sediment derived from individual sources is deposited as overlapping layers instead of as homogeneous mixtures. Such a phenomenon could conceivably occur as a result of a time interval market hy a lick of froe flowing water followed by a resumption of llow (c.g.. drought followed by nash Пloods).

Another mixed sample. Liken from an areit that drains tull units af the Survey Butte. Rainicr Mesa. and Iunnel Beds, as well as clastic units of the I:leana formatlon. Was analyed. Again. the results reveal that dimost all the sediment influx was from one rouk type-in this casc. the affs. However. for this sample, mosl ol the drainatge was from the tuli outcraps, and thus, we could hetier predict the results.

The next step desired in sediment unmixing is o decemine the percent contribution of the various source components to any given sample. This was not possible within the constraints of eur study. llowever, from the strong differences anorge the suurce lithologies examined, it appears that factor analysis may provide such useful information.

Because the alluvium within Yucca Fat is merely the erosional product of the surrounding foothills, it is tikely that the same shape characteristics used to unmix sediment sumples in the surface drainage system could he applied to the subsurfice as well. 11 this is 1ruc. Fourier shape analysis will be an invaluabic tool for correlating liehologics in the subsurface alluvium.

If ue make the conservative assumplion that we cia distinguish only tuff-derived sand lrom that of clas u sources in the subsurface. several very important possihilitics still present themselves. Beciatue only 150 to 200 quarle grims are required lior a sample analysis, the sidew:ll samples will provide the necessitry material. Thus. the samples needed for grain shape analysis have already been laken for most drill holes at the NTS and no additional sampling as needed for preliminary subsurface sludisti.

With gritin shape analysis. we should also be able to deternine the depth at which sand from carhonate sourees is first deposited within the alluvium. That is, besause of the reversed straligraphy effict., "ulf units surrounding Yucca Fit will be eroded and deposited as alluvium before downcutting of the Eleana Formation occurs. In the alluvium, the proportion of carbonate sediment should be zero helow a certiin depth; above this depth, the carbonate portion should increase dramalically. Therefore, to determine the tuffclastic boundary within the alluvium, all we may need to do is exanine histograms of various samples at the second harmonic and identify tbe percentage of grains with high amplitude values (tuff grains).

An additional application of this simple procedure would be to analyze the grain shape frequency distributions of sidewall samples from depth 
zones tentatively identified as debris flow deposits. True debris flows should involve little or no sediment mixing. Constquently, sund grains from flows draining carbonate units shouid be readily identifiable it lite second harmonic.

The potential for unmixing sediment sumples on the basis of these results is very promising. However, the efficiency of the analysis would be greatly enhanced if (1) we could apply factor anulysis to provide a more accurate breakdown of the samples and if (2) we could use a scanning digitizing system.

\section{ACKNOWLEDGMENTS}

The authors thank Nancy Howard for her support and helpful suggestions throughout the course of this project. L-arry McKague. Dick Carlson, and l.eland Younker were instrumental in providing useful discussions and comments on the report. Jerry Richter provided the plotting routine for translating the shape information into machine language. Br. Robert Khrlich (Geology Depart- ment, University of South (arolina) provided all other required computer programs. Glenn Hage rewrote Dr. Ehrlich's programs for use with the equipment and computer language avalable at 1.I.L. Bill McKinnis (NTS) assisted in the field tollection of samples. Bill Beiriger was responsible for organizing and setting up the necessary equipment and materials.

\section{REFERENCES}

1. B. Cirothuus and N. Howard. Correlation of Allstial Deposits at the Nevada Test Site. Lawrence Livermore L.uboratory, Rept. UCRL.-52335 (1977).

2. R. Lhrlich. J. J. Orzeck, and B. Weinberg. "Detrital Quartz as a Natural Tracer-Fourier Grain Shape Analysis." J. Sidimentary Petrology 44, 145-i50 (1974).

3. J. V. Mrukovitch, R. Ehrlich, and B. Weinberg. "New Techniques for Stratigriphic Analysis and Correlation-Fourier Cirain Shape Analysis of Louisiana Offshore Pliocene," J. Sedimentary Petrolog." 46, 226-233 $\{1976\}$.

4. D. S. Van Nicuwenhuise, J. M. Yarus, R. S. Pryzgocki, and R. Ehrlich, "Sources of Shoiling in Charleston Harbor-Fourier Grain Shape Analysis," J. Sedimentary Petrology' 48, 373-383 (1978).

5. R. l:hrlich and B. Weinberg. "An Exact Method for Characterization of Grain Shape," $J$. Sedimentar? Potrology 40. 205-212 (1970).

6. A. B. Cibbons, E. N. Hinrichs, W. R. Hansen, and R. W. Lemke, Geologic Map of the Rainier Mesa Quadrangle. Nye County. Nevada. U.S. Geological Survey. Geological Quadrangle Map GQ-215 (1963).

7. J. M. Yarus, Bedrock Identification by Fourier Grain Shape Analysis of Saprolitic Quartz-South Carolina Piedmont, Master's thesis, University of South Carolina, Columbia, SC (1976).

8. R. S. Pryzgocki, Identificarion of Sediment Sources in a Flwial Neturork-North Carolina Bhe' Ridge-Fouricr Grain Shape Analysis. Master's thesis, University of South Carolina, Columbi.s. SC (1976).

9. A. B. Miall, "Devonian Alluvial Fans, Prince of Wales Island, Arctic Canada," J. Sedimentary Petrolagy" 40. 556-571 (1970). 